\title{
Evaluating the demand for aquaculture insurance: an investigation of fish farmers' willingness to pay in central coastal areas in China
}

\author{
by Zheng, H., Mu, H. and Zhao, X.
}

Copyright, Publisher and Additional Information: This is the author accepted manuscript. The final published version (version of record) is available online via Elsevier.

This version is made available under the CC-BY-ND-NC licence:

https://creativecommons.org/licenses/by-nc-nd/4.0/legalcode

Please refer to any applicable terms of use of the publisher

DOI: https://doi.org/10.1016/j.marpol.2018.08.021

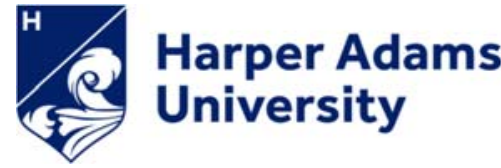




\title{
Evaluating the demand for aquaculture insurance: an investigation of fish farmers' willingness to pay in central coastal areas in China
}

\begin{abstract}
Despite the remarkable development in its fishery sector, the penetration rate of fishery insurance in China is considerably low. This paper examines the key factors that contribute to the poor performance of fishery insurance, in particular aquaculture insurance, in China. The doublebounded dichotomous choice contingent valuation method (DB DCCVM) is used to investigate fish farmers' willingness to pay (WTP) for insurance, based on a survey of 1,280 fish farmers in three coastal cities in China. The results indicate that fish farmers' decisions on adoption of an insurance scheme depend on various factors, among which magnitude of financial loss, fish farmers' awareness toward insurance and their education all have a positive effect on the WTP. However, household income and farming experience are found to have a negative effect. Furthermore, the mean WTP for aquaculture insurance is estimated to be CNY579 (US\$90.05) ${ }^{1}$ per household, which is equivalent to $1.5 \%$ of mean annual household income. These results provide several policy implications for the Chinese government, insurance companies as well as researchers.
\end{abstract}

Keywords China, fishery insurance, aquaculture insurance, willingness to pay (WTP), doublebounded dichotomous choice contingent valuation method (DB DCCVM)

JEL Classification Codes Q22, H42

${ }^{1}$ The exchange rate of 1 US Dollar to Chinese Yuan was 6.43 on $18^{\text {th }}$ June 2018 from Bank of China. 


\title{
Evaluating the demand for aquaculture insurance: an investigation of fish farmers' willingness to pay in central coastal areas in China
}

\author{
Hui Zheng ${ }^{1,3, *}$, Hairong $\mathrm{Mu}^{2}$, Xin Zhao ${ }^{1,3}$ \\ 1. School of Economics, Ocean University of China, Qingdao, Shandong, 266100, China; \\ 2. Department of Land, Farm and Agribusiness Management, Harper Adams University, Newport, \\ Shropshire, TF10 8NB, UK \\ 3. Institute of Marine Development, Ocean University of China, Qingdao, Shandong, 266100, China.
}

\begin{abstract}
Despite the remarkable development in its fishery sector, the penetration rate of fishery insurance in China is considerably low. This paper examines the key factors that contribute to the poor performance of fishery insurance, in particular aquaculture insurance, in China. The doublebounded dichotomous choice contingent valuation method (DB DCCVM) is used to investigate fish farmers' willingness to pay (WTP) for an insurance program, based on a survey of 1,280 fish farmers in three coastal cities in China. The results indicate that fish farmers' decisions on adoption of an insurance scheme depend on various factors, among which magnitude of loss, fish farmers' awareness toward insurance and their education all have a positive impact. However, income and farming years are more likely to have a negative effect. In addition, the mean WTP for aquaculture insurance is estimated to be CNY 579 (US\$ 90.05) ${ }^{2}$ per household, which is equivalent to $1.5 \%$ of fish farmers' mean annual income. These results provide several policy implications for not only the Chinese government but also researchers as well as insurance companies.
\end{abstract}

Keywords China, fishery insurance, aquaculture insurance, willingness to pay (WTP), doublebounded dichotomous choice contingent valuation method (DB DCCVM)

JEL Classification Codes Q22, H42

\footnotetext{
$1 *$ Corresponding author

The first two authors contribute the same to this paper.

Hui Zheng is an associate professor at the School of Economics, Ocean University of China. Email: qdzhouc@163.com;

Hairong $\mathrm{Mu}$ is a senior lecturer at Harper Adams University. Email: hmu@harper-adams.ac.uk; Xin Zhao is a professor at the School of Economics, Ocean University of China. Email: zx@ouc.edu.cn. 2 The exchange rate of 1 US Dollar to Chinese Yuan was 6.43 on $18^{\text {th }}$ June 2018 from Bank of China.
} 


\title{
Evaluating the demand for aquaculture insurance: an investigation of fish farmers' willingness to pay in central coastal areas in China
}

\begin{abstract}
Despite the remarkable development in its fishery sector, the penetration rate of fishery insurance in China is considerably low. This paper examines the key factors that contribute to the poor performance of fishery insurance, in particular aquaculture insurance, in China. The double-bounded dichotomous choice contingent valuation method (DB DCCVM) is used to investigate fish farmers' willingness to pay (WTP) for insurance, based on a survey of 1,280 fish farmers in three coastal cities in China. The results indicate that fish farmers' decisions on adoption of an insurance scheme depend on various factors, among which magnitude of financial loss, fish farmers' awareness toward insurance and their education all have a positive effect on the WTP. However, household income and farming experience are found to have a negative effect. Furthermore, the mean WTP for aquaculture insurance is estimated to be CNY579 (US\$90.05) ${ }^{1}$ per household, which is equivalent to $1.5 \%$ of mean annual household income. These results provide several policy implications for the Chinese government, insurance companies as well as researchers.
\end{abstract}

Keywords China, fishery insurance, aquaculture insurance, willingness to pay (WTP), double-bounded dichotomous choice contingent valuation method (DB DCCVM)

JEL Classification Codes Q22, H42

\section{Introduction}

Fisheries and aquaculture are one of the most important sources of income for millions of people around the world. The most recent estimates from the Food and Agriculture Organization (FAO, 2016) indicate that 56.6 million people across the world were engaged in the primary sector of fisheries and aquaculture in 2014. Of this total population, 25 percent (approximately 14 million people) were in China engaged as fishermen and fish farmers. Over the past decades China's fishery industry has achieved remarkable development. China represents more than $60 \%$ of the world aquaculture production and has remained the major producer for marine fisheries production followed by Indonesia, the United States and Russia (FAO, 2016). In 2016 the total value of production in fisheries was CNY1,200 billion (US\$186.63 billion) (China Fishery Statistical Year Book 中国渔业统计年鉴, 2017), contributing to approximately

\footnotetext{
${ }^{1}$ The exchange rate of 1 US Dollar to Chinese Yuan was 6.43 on $18^{\text {th }}$ June 2018 from Bank of China.
} 
$1.6 \%$ of the nation's GDP. ${ }^{2}$

The fishery sector is broadly divided into capture fishery and aquaculture, both of which are highly dependent on resources and climate and therefore are of high risk. The risks in capture fishery include typhoon, technical failure and accident as well as loss of life and injury on board. In aquaculture there are several factors that can cause production loss and facilities damage such as natural disasters, technical failure, extreme weather and environmental pollution (Yuan et al., 2017). In 2016, various risks caused a total economic loss to fishery and aquaculture in China of approximately CNY28.8 billion (US\$4.48 billion) and the number of the dead, missing and seriously injured people was 165 (China Fishery Statistical Year Book 中国渔业统计年鉴, 2017).

Insurance mechanisms have been widely used in agriculture for risk management as an effective means to mitigate financial risks and to reduce negative impacts of natural catastrophes. An average of $30 \%$ of global economic loss from natural disasters is compensated by insurance. The rate is much higher $(50 \%$ to $60 \%$ ) in the developed countries such as the US and Canada, but considerably lower (less than $2 \%$ ) in China (SIGMA, 2017). Artemis (2016) reported that most of China's US\$41 billion of catastrophic economic losses in 2015 were uninsured and concluded that insurance penetration had not kept pace with the rapidly growing economy. As an important part of agriculture insurance system, fishery insurance in China is still under developed, despite reports of substantial damage and losses every year. For instance, in 2013, although 988,500 fishermen and fish farmers were insured through China Fishery Mutual Insurance Association (CFMI, 中国渔业互保协会), they accounted for only $12.5 \%$ of the total number of people engaged in the sector. In the same year, the total premium income of fishery insurance was CNY1.44 billion (US\$224 million), less than 5\% of the total premium volume of agriculture insurance in China (Guo et al., 2015).

A fishery insurance program in China was initiated in 1982 by the People's Insurance Company of China (PICC, 中国人民保险公司) as part of the company's agriculture insurance services. The scheme was on a small scale and only covered loss of life and injury from accident and damage to fishing vessels. The PICC did not insure aquaculture until 1995 when a pilot scale was undertaken to cover only $2 \%$ of the total aquaculture area in China (Yuan et al., 2017). In spite of continuous support from central and local

\footnotetext{
${ }^{2}$ China's GDP was CNY74,413 billion (US\$11,572 billion) in 2016 (National Bureau of Statistics of China 国 家统计局, 2017).
} 


\section{Overview of fishery insurance in China}

A fishery insurance program in China was initially provided in 1982 by the People's Insurance Company of China (PICC, 中国人民保险公司) as part of the company's agriculture insurance services. Since then fishery insurance has gone through a series of continual adjustments in terms of both programs and practices.

\subsection{Evolution of operational mode of fishery insurance}

A fishery insurance program in China started in accordance with the commercial insurance operational mode and was initially monopolized by the People's Insurance Company of China (PICC, 中国 人民保险公司). In 1985 several other insurance companies entered the market, such as China Ping An 
Ltd. (中国人寿保险股份有限公司) and a few foreign commercial insurance companies. However, confronting with diverse sources of uncertainty and high level of risks associated with fishery and aquaculture, commercial insurance companies were reluctant to get involved in this sector, particularly, in small-scale fisheries and fish-farming activities. In the 1990s, financial loss resulting from operating these insurance businesses became particularly severe due to the lack of policy support from the government. As fishery and aquaculture proved itself to be an expensive class of insurance to handle, most commercial insurance companies pulled out, leaving the PICC alone offering a very limited range of services such as employers' liability insurance and large fishing boat insurance.

In 1995, the PICC began to insure aquaculture on a pilot scale and received a total premium income of CNY9.3 million (US\$1.45 million). Nonetheless, the indemnity paid was CNY18.3 million (US\$2.85 million), which made the loss ratio ${ }^{3}$ of almost 200 percent (Ge and Lou, 1997). As a result of such a huge loss, insurance for aquaculture was ceased in 1996 following high occurrence of disasters abetted by poor farming management. The pilot commercial insurance program for aquaculture was thus deemed unsuccessful. In the meantime, China Fishing Boat Owners Mutual Insurance Association (中国渔船船东 互保协会) was established in July 1994. It was then renamed as China Fishery Mutual Insurance Association (CFMI, 中国渔业互保协会) in October 2007. CFMI aims to help share risks between the owners of fishing vessels, fishermen and fish farmers as well as associated stakeholders. It is a nonprofit organization and regulated by the Ministry of Agriculture and Rural Affairs (MOA, 中华人民共和国农业 农村部). Owners of fishing vessels can join it on a voluntary basis. ${ }^{4}$ This business model effectively helped to alleviate conflicts of interest between commercial insurance companies and the insured. ${ }^{5}$ Over the last decade, fishery mutual insurance has gradually replaced commercial insurance and become the primary operational mode of fishery insurance in China. Between 1994 and 2012, CFMI insured more than 5.57 million fishermen and 350,000 fishing vessels (China Fisheries Association 中国渔业协会, 2013). In

\footnotetext{
${ }^{3}$ Loss ratio is the proportion of indemnity paid to premium earned by the insurer.

${ }^{4} \mathrm{CFMI}$ 's headquarter is in Beijing with nine provincial associations and 30 offices in various provinces.

${ }^{5}$ Mutual insurance by definition is owned entirely by their policyholders. Any profits earned are returned to policyholders in the form of dividend distributions or reduced future premiums. It is different from stock insurance, which, on the other hand, is owned by their shareholders and therefore strive to maximize shareholders' value.
} 
2012, CFMI initiated a pilot insurance program for aquaculture in partnership with commercial insurance companies as well as aquaculture cooperatives and associations. In that year the aquaculture area under the insurance program was around $80,000 \mathrm{mu},{ }^{6}$ which is less than $1 \%$ of China's total aquaculture area (Qin and Zhai, 2015).

Since 2008, there has been increasing financial support for fishery insurance provided by central and local governments at various levels. More commercial insurance companies started to enter the market. Thus the fishery sector in China is currently operated in both mutual and commercial modes.

2.2 Policy support from central and local governments

In order to expand the coverage of fishery insurance, in 2008, the MOA issued "The notice regarding the pilot project of central government's premium subsidies for fishery mutual insurance" (MOA, 2008). This project initiated a trial of subsidized insurance programs in some key fishing areas such as Shandong, Zhejiang, Guangdong, Jiangsu, Hainan, Liaoning and Fujian. Since then a special budget of approximately CNY100,000 (US\$15,552) from central government has been injected annually into fishery insurance programs as direct financial support and subsidies.

In recent years local governments have been following central government's suit to make a great effort in providing various subsidies:

- In 2012 "Implementation of Policy-Oriented Fishery Insurance in Guangdong Province" (GDOFA, 2012) was published. It required local governments at provincial, municipal and county levels to provide $35 \%$ or more subsidies to cover fishermen and fish farmers' personal accident insurance and fishing boat insurance.

- In the meantime, Zhejiang province issued "The Interim Measures for the Management of Special Funds for Subsidies for Fishery Mutual Insurance" (ZJCZT, 2012), which provided 20\% premium subsidies for mutual insurance of fishing boat owners' liability and life insurance.

- In 2014 "The Notice of Implementing Scheme of Agriculture Insurance in Hainan Province" (DFHNP, 2017) was announced. It improved the coverage of fishermen's personal accident insurance to CNY400,000 (US\$62,208) and expanded financial subsidies for fishery mutual insurance to $60 \%$. It further brought fishing boats insurance and fishermen's marine accidents insurance into financial subsidies in 2017.

\footnotetext{
${ }^{6} 1 \mathrm{mu}$ is equal to 0.165 acres.
} 
- On 27 November 2015 "Implementation Plan for Fishery Insurance Pilot in Dalian" (DLOFA, 2015) was published, which marked the first time in Dalian aquaculture insurance started to be implemented.

- On 1 December 2015 "The Circular on Financial Subsidy Policy of Fishery Mutual Insurance in Tianjin" (TJCS, 2015) came into force. The circular stated that fishermen were entitled to receive premium subsidies up to $60 \%$ to cover fishing vessels and life insurance.

- On 6 April 2017 "The Notice of Strengthening Aquaculture Mutual Insurance Pilot in Zhejiang" (ZJOAF, 2017) was published. It stated that premiums could range from CNY22 to 200 per CNY10,000 insurance value.

\subsection{Types of insurance products against various risks}

Fishery insurance can be generally categorized into three types: fishing vessel insurance; life insurance for fishermen and fish farmers; and aquaculture insurance. Most commercial insurance companies underwrite fishing vessel insurance and life insurance, such as China Ping An Insurance (Group) Company Ltd. (中国平安保险 (集团) 股份有限公司), China Pacific Insurance (Group) Co. Ltd. (CPIC, 中国太平洋保险 (集团) 股份有限公司), Tai Ping Life Insurance Co. Ltd. (太平人寿保险有限公司), and China Continent Insurance (中国大地财产保险股份有限公司). But very few commercial companies provide aquaculture insurance services. A brief summary of various types of insurance products is outlined in Table 1.

(Insert Table 1 here)

It can be noted from Table 1 that both CFMI and commercial insurance companies provide cover for damage to fishing vessels and loss of life, but very few companies cover indemnities for losses in aquaculture. It is also worth mentioning that many aquaculture insurance products are provided at regional level on a small scale. Moreover, the details of policies and liabilities are prone to change over time and entirely within discretion of local governments and insurance companies who provide the insurance.

\section{Review of related literature}

Insurance mechanisms have been widely used in agriculture to mitigate financial risks. The factors that affect agricultural output are often evident, such as weather, pest, disease outbreaks and etc. (Mumford 
et al., 2009). However, fishery industry, as an important sector of agriculture, distinguishes itself from more diverse sources of uncertainty and therefore has not been sufficiently covered by insurance policies. Fisheries involve a wide variety of uncertainties such as production, financial, market and institutional risks (Hardaker et al., 2004; Gray and Boehlje, 2005). For aquaculture in particular, with exposure to more uncertainties in catch, prices and revenue variations, insurance companies have less actuarial information on which to base risk assessments associated with production variables in fish farming. Consequently, to reduce operating risks, insurers are inclined to increase premiums which as a result may exceed fish farmers' willingness to pay and in turn further limit the coverage.

As the world's top producer of aquatic products, China's low insurance coverage in aquaculture has attracted a lot of interest. There is a clear consensus in the literature that aquaculture insurance is inconsistent with the rapid development of the sector in China. The main reason is that aquaculture is an industry of high input and high risk. The difficulties in providing aquaculture insurance are mainly reflected in the following aspects: accurate statistical data is incomplete and financial loss is volatile, resulting in difficulties of setting premiums; the farming process has been dynamically changing and thus it is difficult to determine damage (Liu, 2013; Chen et al., 2016). Moreover, the strong technical characteristics of the aquaculture sector also make adverse selection and moral hazard far greater than any other commercial insurance (Sun, 2009; Wang and Li, 2013). All of these explain why the existing aquaculture insurance is operated on a small scale with rules and details of policies varying in regions.

A number of studies recommend adoption of policy-oriented insurance programs ${ }^{7}$ such as premium subsidies as a way forward towards enhancing coverage of aquaculture insurance in China (Sun, 2008; Long and Yang, 2009; Jin and Yang, 2010; Ye and Luo, 2011; Wang and Li, 2013; Chen et al., 2016). However, Mallory (2016) questioned whether China's insurance subsidies are aligned with the country's stated goals in fisheries management by examining China's fisheries policy coherence. She found that approximately $95 \%$ of Chinese fishery subsidies were harmful to sustainability. He (2015) analyzed subsidization trends and tracked the evolution of China's fishery policy objectives and priorities, which showed that historically the Chinese fishery sector had not been significantly subsidized in light of its relatively market-oriented structure.

\footnotetext{
${ }^{7}$ Under 'policy-oriented insurance programs', local governments are encouraged to provide premium subsidies and local mutual associations provide insurance services in collaboration with CFMI and insurance companies. Government policy also aims to reduce operational costs of insurance programs.
} 
In addition to extensive research addressing the issues in fishery insurance in China, a few studies examined the factors influencing demand for fishery insurance. Ye (2010) analyzed demand and supply conditions of fishery insurance in China, and stated that risk level, income, premiums, insurance awareness and subsidies would all affect demand. Wu (2010) used the data from 130 fish farmers in Hubei province and identified the key factors influencing demand for the freshwater aquaculture insurance. Those factors are fish farmers' age, income, fishery species, and financial loss over the years. Jia and Cheng (2015) used the logit model to investigate the factors influencing demand for aquaculture insurance, concluding that fish farmers' age, income, previous losses, compensation and insurance knowledge were positively correlated with demand, but premiums exhibited an opposite correlation. However, all these studies do not distinguish between different types of fishery insurance, and none of them have attempted to estimate fish farmers' WTP, which is a key information for insurance companies and policy makers to understand in order to improve coverage of aquaculture insurance in China.

WTP is the amount of money an individual is willing to use in purchasing a product given a number of characteristics such as income, risk perception and level of risk aversion (Ali, 2013). The concept first appeared in economic literature more than a century ago and was designed to determine prices for pure public goods and services. Since people's perceptions and attitudes can influence their WTP, it is necessary to investigate their perceptions and attitudes in order to evaluate the real demand and set an affordable premium level. The WTP and factors that influence demand for agriculture insurance have been extensively studied (McCarthy, 2003; Choi et al., 2007; Hill et al., 2013; Gu and Lu, 2016). However, very little has been examined with regard to fish farmers' WTP and the issues of low insurance penetration in aquaculture. Some researchers have acknowledged poor performance of insurance in the fishing community. For example, Parappurathu et al. (2017) addressed the issues of fishery insurance in India and identified various factors that contributed to low coverage of fisheries insurance in the country. But they did not look into fish farmers' WTP and address the problem from their perspective. To our best knowledge, the only survey to estimate fishermen's WTP in an insurance program was undertaken in Oman in 2006 (Zekri et al., 2008), which involved 210 small-scale fishermen to estimate annual insurance premiums.

\section{Theoretical framework and basic assumptions}


Aquaculture insurance, as one type of quasi-public goods, aims to provide insurance services for individuals earning a living from fish farming. According to the fundamental concepts of welfare economics and expected utility theory, utility maximization is a primary objective of policyholders, who are always risk averse. However, obtaining the maximized utility is subject to several factors that determine policyholders' WTP for aquaculture insurance. Based on the knowledge of the current status of aquaculture insurance in China and the existing literature, we proposed the following four hypothesis that can affect fish farmers' WTP.

Hypothesis 1: The low affordability of fish farmers for insurance limits their WTP. Small-scale decentralization is one of the outstanding characteristics of China's aquaculture sector. Most fish farmers are of low income with weak capacity to resist risks. This can limit their WTP and result in insufficient demand for aquaculture insurance.

Hypothesis 2: The large gap between the current government subsidies and the actual need of fish farmers does not help to raise the level of insurance coverage.

Fishery mutual insurance mainly relied on its own funding to expand business in absence of financial subsidies at its early stage. Since 2008, the Ministry of Agriculture and Rural Affairs (农业农村部) has allocated CNY10 million to mutual insurance associations to promote and strengthen mutual support for fishery insurance. Some local governments have also provided fishery mutual insurance subsidies. However, given the large population of fish farmers who are in great need for insurance but have weak purchasing power, the governments' financial subsidies are inadequate.

Hypothesis 3: The unique characteristics of production in aquaculture sector make it very difficult to assess the insurability of various risks.

On the one hand, currently the dispersed small-scale production in aquaculture cannot provide accurate and reliable data with reference to diverse water quality, density of livestock, loss history and so on, which consequently affects insurance eligibility of some fish farmers. In addition, it becomes more problematic with calculation of stock, estimation of product value and inspection of accident losses. On the other hand, fearing of moral hazard, insurance companies tend to raise premiums in order to protect themselves against high risk and cover their high operating costs, which in turn discourages fish farmers from participating in insurance programs.

Hypothesis 4: Lack of awareness and understanding of insurance can be attributed to the causes of 
fish farmers' resistance to aquaculture insurance.

As China's fishery insurance market in general is less developed, it does not have an established publicity mechanism for aquaculture insurance. With a relatively low level of education, most Chinese fish farmers are ignorant of insurance, particularly they lack the knowledge of aquaculture insurance. Therefore, it is not surprising that they resist purchasing unfamiliar insurance services for potential compensation.

\section{Data sources and methodology}

5.1 Study area and data collection

The extent and scope of marine natural risks vary across coastal regions from southeast to north in China. Shandong province is located in the Bohai Rim and rated at medium risk level in terms of marine disaster. It is a major agriculture production area, and in 2008 became one of the first pilot provinces for China's fishery insurance. The consumption per capita in Shandong is close to average among all coastal areas in China (NBS, 2017). At present there is no formal aquaculture insurance in Shandong province and thus this research is of high relevance in practice when aquaculture insurance policies are designed and structured. The specific study area for this research includes Qingdao, Yantai and Weihai in Shandong province. These three cities are typical aquaculture farming regions in Shandong province and have been suffering severe financial losses in aquaculture production every year. Figure 1 presents a map of China and location of the study area.

\section{(Insert Figure 1 here)}

The data used in this study were collected from a survey of 1,280 fish farmers who were randomly selected from the above mentioned three cities. ${ }^{8}$

\subsection{Key variables}

Table 4 (see Appendix) presents the key variables used to verify the hypothesis in the survey. Personal variables capture fish farmers' demographic information such as their age and farming experience. With the characteristics of small-scale and dispersed production, older fish farmers are deeply influenced by traditional working models and thus prefer to borrow money or to seek help from their relatives and

\footnotetext{
${ }^{8}$ The questionnaires were distributed to the fish farmers who were registered at local agricultural cooperatives and were able to be interviewed. Each respondent was informed of the survey aim, i.e. to investigate the willingness to pay for aquaculture insurance. It was also explained to them that the result of the survey would be only used to provide information for policy recommendation and not be used to inform actual prices.
} 
friends rather than to purchase insurance to cover the risk of financial loss. As they grow older and their farming experience accumulates, fish farmers' ability to respond to natural risks becomes stronger. Similarly in agriculture insurance both age and farming experience have also been found to impose a negative impact on policyholders' WTP (Spence et al., 2011; Bradford et al., 2012; Hill et al., 2013; Teshome and Bogale, 2015).

Social variables represent the basic characteristics of fish farmers' family, including household size, proportion of household members in labour force (including all types of employment in the household), and average annual household income. Household size is expected to have a negative impact on fish farmers' demand for insurance, because a bigger household needs more money to cover fixed expenditure and as a result little is left to be spent on insurance (Tian and Yao, 2015). The financial burden can be effectively alleviated if a high proportion of household members are in labour force and if the household receives a high income. This enables them to cope with natural disasters but meanwhile reduces their WTP for insurance (Bhutto and Bazmi, 2007). Some studies have also noted that fish farmers' demand for insurance has a significant correlation with their affordability of insurance premiums (Chien and Yeh, 2009).

Risk variables reflect risk exposure by landholding per member of household and financial loss suffered by fish farmers in the previous years. Those who have suffered huge losses are keen to participate in insurance programs, but they may be incentivized to provide misleading information in order to receive a low premium. This can lead to the situation where those fish farmers with lower risks are squeezed out of the market. ${ }^{9}$

Attitude variables mainly focus on fish farmers' education and their awareness toward insurance. There exists a notable relationship between these two variables (Hill et al., 2013). It is widely accepted that the more educated people are, the more likely they are to take extensive and in-depth risk prevention measures (Burn, 1999; Choi et al., 2007; Seifert et al., 2013; Zhang and Stenger, 2014). Overall insurance awareness indirectly reflects fish farmers' knowledge of aquaculture insurance, thereby influencing their WTP (Azam et al., 2012; Botzen and van den Bergh, 2012; Brunette et al., 2015; Qin et al., 2016).

\subsection{Analytical approach}

There are many methods used to measure the WTP, based on either sales data or survey data. Since

\footnotetext{
${ }^{9}$ This is the case when moral hazard occurs.
} 
there is currently lack of existing sales data for aquaculture insurance in China due to the reasons explained earlier, fish farmers' WTP can be only elicited from survey data. It is worth noting that calculation of the WTP based on survey data may suffer from application or measurement problems. The hypothetical bias can appear when, placed in a hypothetical situation, particularly in the context of a questionnaire, the respondent does not consider all the constraints that would affect his choice in a real situation. Therefore, there is a difference between what the respondent says and what he could accept to pay in a real situation. A strategic bias can also arise when respondents deliberately formulate their answers to influence the outcome of the survey to further their own interests, which consequently can affect results (Le Gall-Ely, 2009). However, despite the possible biased estimates due to the hypothetical data, the contingent valuation method (CVM) is still believed to be a practical alternative approach for estimating the WTP and hypothetical bias can be minimized or eliminated through a well-designed questionnaire (Carson, 2012).

In this study, the double-bounded dichotomous choice contingent valuation method (DB DCCVM) was adopted to elicit fish farmers' WTP. The DB DCCVM model has been the most popular method of CVM due to its simplicity of use in data collection. It asks each respondent a sequence of two questions as to whether he or she would be willing to pay some specified amounts of money to obtain the non-marketed goods. The respondents required to answer YES or NO when asked if he/she is willing to pay a given amount (bid) for the good. In the DB DCCVM model the first question is followed by another specifying a lower amount, if the answer to the first question was negative and higher otherwise. Thus the DB DCCVM is more efficient than the single bounded mode ${ }^{10}$ in solving poor choice of initial bids (Hanemann, 1991). We proposed five hypothetical premiums as initial bids in this research (see Table 2). The five starting bids (CNY50, CNY150, CNY250, CNY350, and CNY450 per household per year) ${ }^{11}$ were given randomly to each respondent in order to avoid starting-bid bias (Akter et al., 2011).

(Insert Table 2 here)

The outcomes of face-to-face survey fall into four categories:

a. Accepting both the initial and the follow-up bids (YY)

b. Accepting the initial bid but rejecting the follow-up bid (YN)

\footnotetext{
${ }^{10}$ The single bound model comprises of only one such question for a respondent to answer YES or NO to a specified bid.

${ }^{11}$ The five proposed starting bids are close approximation and fall in the range of actual premiums of those limited existing aquaculture insurance products (see Table 1).
} 
c. Rejecting the initial bid but accepting the follow-up bid (NY)

d. Rejecting both the initial and the follow-up bids (NN)

The factors affecting the WTP were then analyzed by a double-bounded logit model as follows

$$
\mathrm{Y}_{\mathrm{i}}=\alpha \mathrm{X}_{1 \mathrm{i}}+\beta \mathrm{X}_{2 \mathrm{i}}+\varepsilon_{\mathrm{i}} \quad i=1, \cdots, \mathrm{n}
$$

Where $Y_{i}$ denotes fish farmer i's true willingness to pay for aquaculture insurance; $X_{1 \mathrm{i}}$ is a vector of the selected variables; $\mathrm{X}_{2 \mathrm{i}}$ is the ultimate bidding premium provided to fish farmer $\mathrm{i} ; \varepsilon$ is a random variable, including possibly unobservable characteristics influencing the final decision. So the specification of the equation is

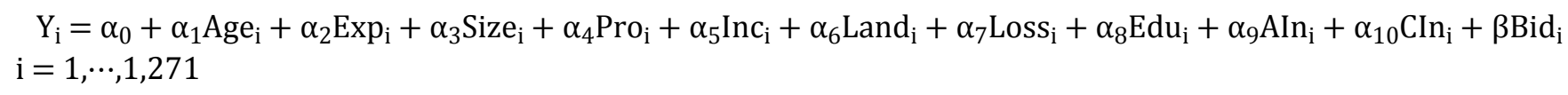

Where

$\mathrm{Age}_{\mathrm{i}}=$ Fish farmer's age;

$\operatorname{Exp}_{\mathrm{i}}=$ Farming experience, measured by years;

Size $_{\mathrm{i}}=$ Household size, measured by the number of people in households;

$\operatorname{Pro}_{\mathrm{i}}=$ Proportion of household members in labour force;

$\mathrm{Inc}_{\mathrm{i}}=$ Average annual household income, in CNY;

Land $_{\mathrm{i}}=$ Landholding per member of household, in acres;

Loss $_{\mathrm{i}}=$ Average annual loss of household, in CNY;

$E d u_{i}=$ Discrete education level of the household held, measured by years;

$\mathrm{AIn}_{\mathrm{i}}=$ Awareness towards aquaculture insurance;

$\mathrm{CIn}_{\mathrm{i}}=$ Awareness towards other commercial insurance;

$\mathrm{Bid}_{\mathrm{i}}=$ the ultimate bidding premium provided to fish farmer $\mathrm{i}$.

The responding probabilities are calculated for the double-bounded logit model (Hanemann, 1991).

$$
\begin{aligned}
\mathrm{P}_{i}^{Y Y} & =1 /\left(1+e^{-(\alpha+\beta \mathrm{HB})}\right) \\
\mathrm{P}_{i}^{N N} & =1-1 /\left(1+e^{-(\alpha+\beta L \mathrm{~B})}\right) \\
\mathrm{P}_{i}^{Y N} & =1 /\left(1+e^{-(\alpha+\beta \mathrm{HB})}\right)-1 /\left(1+e^{-(\alpha+\beta \mathrm{IB})}\right) \\
\mathrm{P}_{i}^{N Y} & =1 /\left(1+e^{-(\alpha+\beta \mathrm{IB})}\right)-1 /\left(1+e^{-(\alpha+\beta \mathrm{LB})}\right)
\end{aligned}
$$

Where

$$
\text { IB = Initial bid }
$$




\section{Results and discussion}

\subsection{Statistical results of the WTP responses}

Out of 1,280 fisher farmers who were surveyed, the valid responses from 1,271 fish farmers indicate that 796 of them, accounting for approximately $62.63 \%$ of the total sample, are willing to purchase insurance. The statistical results are presented in Table 4 (see Appendix).

When examining the WTP in different age groups the highest proportion can be observed from fish farmers aged below 20, while lowest proportion from those aged over 60 . The WTP increases gradually with fish farmers' experience in aquaculture production and peaks when they have engaged in the sector for $16-25$ years.

The WTP increases as household size rises. About $85.5 \%$ households of more than 6 members are willing to purchase aquaculture insurance. Fish farmers' demand for insurance does not demonstrate a specific tendency as their income increases. The household of less than one quarter in the labour force reveals the highest willingness to pay at $94.7 \%$ and has a monotonic decreasing relationship with the 
The highest proportion of the WTP can be also identified from the group in which landholding per member of household is 1-3 acres. Those with an annual average loss under CNY2,000 and more than CNY6,000 demonstrate the lowest and highest proportion of the WTP for insurance, respectively.

The data also show that the WTP has a positive correlation with fish farmers' education level. It is found that 935 fish farmers know about aquaculture insurance and 805 fish farmers have heard of other types of commercial insurance.

Table 5 (see Appendix) presents the descriptive statistics of the WTP responses. It is obvious to note that the respondents with higher education level and insurance awareness responded positively to both initial and follow-up higher bids. Meanwhile, the respondents who accepted both bids own much more land per person and suffer greater annual loss than those who declined both bids. Household size also exhibits a positive correlation with the WTP responses, while the proportion of household members in labour force indicates a negative correlation. The older fish farmers with more farming experience are more likely to decline both bids. A bit surprisingly, those who tend to accept both bids are the ones who have the lowest average annual income.

\subsection{Results of regression}

The regression results are given in Table 3. It is noted that all of the variables demonstrate a significant correlation with the WTP, which is not in line with the results of previous studies (Hill et al., 2013; Khan et al., 2013). The results have revealed that the majority of fish farmers respond positively to the bids, and the negative coefficient of the bid value indicates that a lower price would be more affordable. The mean WTP for aquaculture insurance is calculated at CNY579 per household, which represents $1.5 \%$ of mean annual household income. This estimation provides valuable information for insurance companies when setting premiums.

\section{(Insert Table 3 here)}

Education level and annual average loss are found to have a positive effect on the WTP, which implies better educated fish farmers and those who have suffered serious losses are more likely to purchase insurance. The same result was also found by Akter (2009). It is also notable from the regression results that awareness towards insurance has a positive effect on the WTP and the coefficients for these two

\footnotetext{
${ }^{12}$ Partnerships or employed labourers are also included in manpower to guarantee the accuracy of the data.
} 
variables present fairly significant values. This is a similar result to that of Shields (2015). Different from previous studies in disaster insurance or agriculture insurance, household size imposes a positive effect on the WTP. This is because a larger household normally operates on a bigger scale and owns larger aquaculture lands, therefore, has a stronger desire to purchase aquaculture insurance to cover relatively high potential risks. Furthermore, there exist complicated interactions between education, household size and farming experience. More education can make fish farmers more knowledgeable. A larger household means there are more members in a family who can bring back more information about various methods of risk management, which strengthens their WTP. It is verified that the more educated younger fish farmers rely more on commercial insurance as a practical mechanism against risks. Moreover, the more serious loss of household assets caused by previous natural disaster can lead to a higher WTP. Thus, both financial loss and education can be attributed to higher WTP.

However, age, farming experience and proportion of household members in labour force all have a negative effect on the WTP. The statistics illustrate that older fish farmers with longer farming experience are more reluctant to join insurance schemes, as most of them know little about financial options against disasters and risks. If the proportion of household members in labour force increases due to more members in the household joining in non-fishery sector, the household can receive income elsewhere and become financially capable of coping with risks in the fishery sector, which adversely affect their WTP for aquaculture insurance. The situation can be even worse if the increase of the proportion of household members in labour force is a result of more members in the household joining in fishery sector. Because the higher proportion of the household engaging in fishing activities often implies a lower education level of the household (Sun et al., 2010; Wang, 2011; Guo and Gao, 2014), thus it further reduces fish farmers' WTP for insurance. It is reconfirmed that income plays a negative role in decision making of insurance adoption, i.e. higher income does not predict a higher WTP. Furthermore, increased farming experience and income reduce the likelihood of accepting a higher premium bid. It is easier for those who have strong capital strength, high credit score and good production capability to acquire financial assistance from banks and governments, which consequently reduces their demand for aquaculture insurance. This finding provides particularly useful insight for making policies and designing aquaculture insurance cooperation mechanism in China. 
Despite of the remarkable development and promising future growth potential, China's fishery sector has been confronted with a relatively low penetration of insurance. There has been a growing concern with poor adoption of fishery insurance, in particular aquaculture insurance, in China and some studies have attempted to examine the causes behind the situation. However, it is still not clear what factors are associated with fish farmers' decision on adoption of aquaculture insurance in China. To find the answer to the question, this study collected data from a survey of 1,280 fish farmers in three coastal cities in Shandong province, i.e. Qingdao, Yantai and Weihai. Moreover, a double-bounded dichotomous choice contingent valuation method (DB DCCVM) was adopted to estimate fish farmers' WTP, which provides valuable information for insurance companies and policy makers.

All the variables exhibit statistically significant but different effects on the WTP. Some factors have a positive effect, such as household size, education, landholding per member of household, annual average loss, and level of awareness towards insurance. But other factors have a negative effect such as age, farming experience, average annual household income and proportion of household members in labour force. Older people with more farming experience are more likely to have a lower education level, which makes them ignorant of insurance. The landholding per member of household and annual average loss of household directly reflect the degree of risk exposure and are the key drive for fish farmers to purchase aquaculture insurance.

A striking finding is that income, a key factor determining fish farmers' affordability for insurance, has an unexpectedly negative effect on the WTP for aquaculture insurance. It can be explained that higher income approves a higher credit score, which enables those fish farmers to access to various financial resources to meet their need for risk diversification and compensation for loss. In addition, moral hazard is particularly a problem in the insurance market and consequently those with high income and low risk can be easily crowded out by those with low income and high risk. Without any doubt, increasing subsidies and reducing premiums can be appealing to both higher- and lower-income groups to participate in insurance programs. However, what concerns those of higher-income is whether aquaculture insurance can meet their diversified need, i.e. to provide more risk management channels and options for loss compensation as well as credit financing and guarantee.

Fishery production in China has been less industrialized and thus operated in a labor-intensive model. 
Fish farmers would prefer to improve income by simply increasing labor force to boost output, which seems the easiest and cheapest way to achieve their goals, rather than to purchase insurance to avoid risks to secure income. Besides, when choosing an insurance product, fish farmers care more about whether the service can provide sufficient protection against risks at affordable prices. The results of the survey have confirmed that hypothesis 3 and 4 provide a sound explanation for why China's aquaculture insurance has had such a poor performance from fish farmers' perspective, i.e. inadequate governments' financial subsidies and difficulty of assessing the insurability of various risks due to dispersed small scale production.

To encourage fish farmers' participation, the coverage of aquaculture insurance should be extended to mariculture and marine processing as well as recreation fishing sectors, so as to meet diverse needs from a wider fishing community. In addition, financial support for aquaculture insurance provided by the government should be divided into supply-side and demand-side subsidies. Supply-side subsidy would help to fill the gap between operating cost and premium revenue of insurance companies, and thus incentivize more commercial insurance companies to enter the market. Demand-side subsidy would provide income support to motivate fish farmers' participation in aquaculture insurance. Although increasing the amount of the subsidies can be effective to increase motivation on both sides (Abbas et al., 2015; Khan et al., 2013; Zheng and Wang, 2015), it is more useful to set discriminated premiums based on risk levels as well as fish farmers' financial status and credit score. This can effectively reduce the risk of adverse selection in the market and improve fish farmers' affordability for aquaculture insurance and bring a relatively high degree protection to those who have a lower risk level. Besides, policymakers should put effort into raising awareness and improving education by spreading the word about the importance of having insurance through various channels (Teweldemedhin and Kafidii, 2009). Insurance companies are advised to be more active in using the Internet and social media to promote their insurance products as well as develop social awareness of insurance in particular in rural areas where fish farmers need to be educated to appreciate the benefits of having insurance.

\section{Acknowledgement}

This work was supported in part by the National Natural Science Foundation of China (Grant No. 71503238). 


\section{References:}

AAIC (Shanghai Anxin Agricultural Insurance Co. Ltd., 上海安信农业保险有限公司). Not dated. "Anxin Escort Shield" Fishing Boat Comprehensive Insurance (安信护航盾群众渔船综合保险). [Online]. Available from: http://www.aaic.com.cn/yangzhiyebaoxian/1503.jhtml [Accessed 9 August 2018].

AAIC (Shanghai Anxin Agricultural Insurance Co. Ltd., 上海安信农业保险有限公司). Not dated. "Safe to Fortis" Aquaculture Insurance (安信致富通水产养殖保险). [Online]. Available from: http://www.aaic.com.cn/yangzhiyebaoxian/1503.jhtml [Accessed 9 August 2018].

Abbas, A., Amjath-Babu, T.S., Kächele, H. and Müller, K. 2015. Non-structural Flood Risk Mitigation under Developing Country Conditions: an Analysis on the Determinants of Willingness to Pay for Flood Insurance in Rural Pakistan. Natural Hazards 75(3): 2119-2135.

Akter, S., Brouwer, R., Van Beukering, P.J., French, L., Silver, E., Choudhury, S. and Aziz, S.S. 2011. Exploring the Feasibility of Private Micro Flood Insurance Provision in Bangladesh. Disasters 35: 287307.

Ali, A. 2013. Farmers' Willingness to Pay for Index Based Crop Insurance in Pakistan: A Case Study on Food and Cash Crops of Rain-fed Areas. Agricultural Economics Research Review 26(2): 241-248.

Artemis. 2016. China's \$41bn of 2015 Catastrophe Economic Losses Largely Uninsured. [Online]. Available from: http://www.artemis.bm/blog/2016/01/14/chinas-41bn-of-2015-catastrophe-economiclosses-largely-uninsured/ [Accessed 9 August 2018].

Azam, K., Yussof, R. and Khan, A. 2012. The Role of Coping Capacities in Disaster Perspective: a Case of Pakistan Flash Floods 2010. International Journal of Sustainable Development 4(3): 109-126.

Bhutto, A.W. and Bazmi, A.A. 2007. Sustainable Agriculture and Eradication of Rural Poverty in Pakistan. Natural Resources Forum 31: 253-262.

Bockstael, N.E. and Strand, I.E. 1987. The Effect of Common Source of Regression Error on Benefit Estimates. Land Economics 63(1): 11-20.

Botzen, W.J.W. and van den Bergh, J.C.J.M. 2012. Risk Attitudes to Low-probability Climate Change Risks: WTP for Flood Insurance. Journal of Economic Behavior Organization 82: 151-166.

Bradford, R.A., O'Sullivan, J.J., van der Craats, I.M., Krywkow, J., Rotko, P., Aaltonen, J., Bonaiuto, M., DeDominicis, S., Waylen, K. and Schelfaut, K. 2012. Risk Perception-issues for Flood Management in Europe. Natural Hazards and Earth System Science 12(7): 2299-2309.

Brunette, M., Holecy, J., Sedliak, M., Tucek, J. and Hanewinkel, M. 2015. An Actuarial Model of Forest Insurance against Multiple Natural Hazards in Fir (Abies Alba Mill.) Stands in Slovakia. Forest Policy and Economics 55: 46-57.

Burn, D.H. 1999. Perceptions of Flood Risk: a Case Study of the Red River Flood of 1997. Water Resources Research 35: 3451-3458.

CFMI (China Fishery Mutual Insurance Association, 中国渔业互保协会). 2016. Employers' Foreign Mutual Liability Insurance (Nansha) (雇主南沙涉外责任互助保险). [Online]. Available from: http://www.cfmi.org.cn/index.php?m=content\&c=index\&a=show\&catid=106\&id=152 [Accessed 9 August 2018]. 
CFMI (China Fishery Mutual Insurance Association, 中国渔业互保协会). 2016. Employers' Liability Mutual Insurance (雇 主 责任互助保 险 ). [Online]. Available from: http://www.cfmi.org.cn/index.php?m=content\&c=index\&a=show\&catid=106\&id=153 [Accessed 9 August 2018].

CFMI (China Fishery Mutual Insurance Association, 中国渔业互保协会). 2016. Fishing Boat Insurance (Hainan Province) (海南省渔船共保体渔船保险). [Online]. Available from: http://www.cfmi.org.cn/index.php?m=content\&c=index\&a=show\&catid=106\&id=154 [Accessed 9 August 2018].

CFMI (China Fishery Mutual Insurance Association, 中国渔业互保协会). 2016. Fishing Boat Mutual Insurance (渔船互助保险 ). [Online]. Available from: http://www.cfmi.org.cn/index.php?m=content\&c=index\&a=show\&catid=106\&id=156 [Accessed 9 August 2018].

CFMI (China Fishery Mutual Insurance Association, 中国渔业互保协会). 2016. Nansha Fishing Boat Foreign Mutual Insurance (渔船南沙涉外互助保险). [Online]. Available from: http://www.cfmi.org.cn/index.php?m=content\&c=index\&a=show\&catid=106\&id=157 [Accessed 9 August 2018].

CFMI (China Fishery Mutual Insurance Association, 中国渔业互保协会). 2016. Personal Accident Insurance at Sea (Hainan Province) (海南省渔民共保体渔民海上人身意外伤害保险). [Online]. Available from: http://www.cfmi.org.cn/index.php?m=content\&c=index\&a=show\&catid=106\&id=155 [Accessed 9 August 2018].

CFMI (China Fishery Mutual Insurance Association, 中国渔业互保协会). 2016. Personal Safety Mutual Insurance (渔民人身平安互助保险 ). [Online]. Available from: http://www.cfmi.org.cn/index.php?m=content\&c=index\&a=show\&catid=106\&id=158 [Accessed 9 August 2018].

CNTAIPING (China Taiping Insurance Group, 中国太平保险集团). not dated. Fishing Boat Commercial Insurance (渔 船 保 险 ). [Online]. Available from: http://www.cntaiping.com/upload/cms/caixian/201806/tcbxcbK2697849.pdf [Accessed 9 August 2018]. Carson, R.T. 2012. Contingent Valuation: A Practical Alternative When Prices Aren't Available. Journal of Economics Perspective 26: 27-42.

Chen, X., Li, M. and Zhang, Y. (陈学洲, 李苗, 张溢卓). 2016. Analysis of Current Situation of Aquaculture Insurance in China and Policy Recommendations: Taking Examples of Guangdong, Zhejiang, Ningbo, Shanghai and other places (中国水产养殖保险的现状分析及政策建议一一广 东、浙江、宁波、上海等地为例). China Fisheries (中国水产) 5: 38-40.

Chien, L.H. and Yeh, M.H. 2009. Information, Risk Perception and Disease Insurance Decision. The International Journal of Economic Policy Studies 4: 185-201. 
China Fisheries Association (中国渔业协会). 2013. Comparative Analysis on the Development Experiences of China and International Fishery Insurance: A Case Study of Japan, Korea and France (中国与国际渔业保险发展经验的对比分析一一日本、韩国、法国为例). [Online]. Available from: http://www.china-cfa.org/hotnew_9.asp [Accessed 9 August 2018].

China Fishery Statistical Year Book (中国渔业统计年鉴). 2017. [Online]. Available from: http://www.cme.gov.cn/node/52.jspx? Flag =yd [Accessed 29 June 2018].

Choi, Y., Choi, Y.S. and Kim, Y.T. 2007. Willingness to Pay on the Flood Risk Perception of Residents Employing Cumulative Logit Model. Journal of the Korean Society of Civil Engineers Magazine 27: 629-637.

Cooper, J. C. 1999. Referendum CVM programs. Economic Research Service, USDA, Washington.

DFHNP (Department of Finance of Hainan Province, 海南省财政厅). 2017. Notice of Implementing Scheme of Agriculture Insurance in Hainan Province. (海南省农业保险实施方案). [Online]. Available from: http://mof.hainan.gov.cn/czt/tslm/nybxsd/nxzc/201707/t20170711_2367592.html [Accessed 9 August 2018].

DLOFA (Oceanic and Fisheries Administrator of Dalian, 大连市海洋与渔业局). 2015. Implementation Plan for Fishery Insurance Pilot in Dalian (大连市渔业保险试点实施方案). [Online]. Available from: http://www.lnhyw.gov.cn/xzwgk/gzdt/yyfz/201511/t20151116_1960366.html [Accessed 9 August 2018].

FAO (Food and Agriculture Organization of the United Nations). 2016. The State of World Fisheries and Aquaculture. [Online]. Available from: www.fao.org/3/a-i5555e.pdf [Accessed 9 August 2018].

FFMI (Fujian Fishery Mutual Insurance Association, 福建省渔业互保协会). 2018. Typhoon Index Aquaculture Insurance (水产养殖台风指数保险). [Online]. Available from: http://www.ffmi.com.cn/a/xiehuidongtai/20180503/2293.html [Accessed 9 August 2018].

GAPI (Groupama-AVIC Property Insurance Co., Ltd., 中航安盟财产保险有限公司). Not dated. Aquaculture Insurance (淡水养殖保险). [Online]. Available from: http://www.groupamaavic.com.cn/nongyexian/yangzhixian [Accessed 9 August 2018].

GDOFA (Oceanic and Fisheries Administrator of Guangdong Province, 广东省海洋与渔业厅). 2012. Implementation of Policy-Oriented Fishery Insurance in Guangdong Province (广东省政策性渔业保 险 实 施 方 案 ). [Online]. Available from: http://jiuban.moa.gov.cn/sjzz/yzjzw/yyywyzj/201208/t20120827_2898602.htm [Accessed 9 August 2018].

Guo, X. and Gao, J. (郭晓蓉, 高健). 2014. The Investigation of Marine Fishing Village Economy and Social Status: the Ocean Fishing Village in Ningbo (海洋捕捞渔村经济社会现状的调查研究一以 宁波海洋捕捞渔村为例). Chinese Fisheries Economics (中国渔业经济) 3: 28-32.

Ge, G. and Lou, Y. (葛光华, 楼永). 1997. Current Status and Prospect of China Fishery Insurance (中国渔 业保险的现状及发展前景). China Fishery Economy Research (中国渔业经济研究) 6: 22-23. 
Gray, A.W. and Boehlje, M. 2005. Risk Sharing and Transactions Costs in Producer-Processor Supply Chains, Choices 20(4): 281-286.

Gu, Z. and Lu, Y. (谷政, 卢亚娟). 2016. Analysis of the Demand for Weather Index Agricultural Insurance on Household Level in Anhui (农户购买天气保险意愿的影响因素分析). Journal of Financial Development Research (金融发展研究) 3: 179-186.

Guo, W., Li, P., Lin, L., and Wu, J. (郭玮, 李攀辉, 林琳, 伍京华). 2015. Fishery Mutual Assistance Insurance is a Successful Example of Agricultural Insurance and should be Strongly Supported (渔业 互助保险是农业保险发展的成功范例应予大力扶持). China's Economic and Social Development Situation and Countermeasures - Research Results of the Research Office of the State Council (中国经 济社会发展形势与对策-国务院研究室调研成果选). China Yan Shi Press (中国言实出版社).

GYNYBX (Guoyuan Agricultural Insurance Co., Ltd., 国元农业保险股份有限公司). not dated. Aquaculture Insurance (淡 水养殖保险 ). [Online]. Available from: http://www.gynybx.com.cn/info/1240.jspx [Accessed 9 August 2018].

Hanemann, W.M. 1991. Willingness to Pay and Willingness to Accept: How Much can They Differ?. The American Economic Review 81: 635-647.

Hardaker, J. B., Huirne, R. B. M., Anderson, J. R. and Lien, G. 2004. Coping with Risk in Agriculture. CAB International, Wallingford, UK.

He, J. 2015. Chinese Public Policy on Fisheries Subsidies: Reconciling Trade, Environmental and Food Security Stakes. Marine Policy 56: 106-116.

Hill, R.V., Hoddinott, J. and Kumar, N. 2013. Adoption of Weather-index Insurance: Learning from Willingness to Pay among a Panel of Households in Rural Ethiopia. Agricultural Economics 44: 385398.

Jia, Q. and Chen, S. (贾清茹, 陈盛伟). 2015. Empirical Analysis on Factors Affecting the Development of Aquaculture Insurance in Coastal Areas of Shandong Province (山东省沿海地区水产养殖保险发展 影响因素实证分析). Xinjiang State Farms Economy (新疆农垦经济) 4: 83-90.

Jin, L. and Yang, Y. (金麟根, 杨云聪). 2010. Analysis of Policy-Oriented Fishery Insurance in China (我国 政策性渔业保险浅析). Guangdong Agricultural Sciences (广东农业科学) 2: 309-312.

Khan, M.A., Chander, M. and Bardhan, D. 2013. Willingness to Pay for Cattle and Buffalo Insurance: an Analysis of Dairy Farmers in Central India. Tropical Animal Health and Production 45(2): 461-468.

Le Gall-Ely, M. 2009. Definition, Measurement and Determinants of the Consumer's Willingness to Pay: a Critical Synthesis and Directions for Further Research. Recherche et Applicatoins en Marketing (French Edition), SAGE Publications 24(2): 91-113.

Liu, X. (刘祥祥). 2013. Analysis of Aquaculture Insurance in China (我国水产养殖保险的探析). Shanghai Insurance (上海保险) 9: 42-47.

Long, J. and Yang, Y. (龙江, 杨玉良). 2009. Problems and Models of Policy-Oriented Insurance in Aquaculture in China (我国水产养殖政策性保险存在的问题及模式探究). Livestock and Feed 

业部关于下达 2008 年渔业互助保险中央财政保费补贴试点项目资金的通知). [Online]. Available from: http://www.moa.gov.cn/govpublic/CWS/201006/t20100606_1533369.htm [Accessed 9 August 2018].

Mumford, J.D., Leach, A.W., Levontin, P. and Kell, L.T. 2009. Insurance Mechanisms to Mediate Economic Risks in Marine Fisheries. ICES Journal of Marine Science 66(5): 950-959.

NBS (National Bureau of Statistics of China, 中国国家统计局). 2017. [Online]. Available from:

http://www.stats.gov.cn/ [Accessed 9 August 2018].

Parappurathu, S., Ramachandran, C., Gopalakrishnan, A., Kumar, D., Poddar, M.K., Choudhury, M., Geetha, R., Koya, K.M., Kumar, R.N. and Salini, K.P. 2017. What Ails Fisheries Insurance in India? An Assessment of Issues, Challenges and Future Potential. Marine Policy 86: 144-155.

Park, T., Loomis, J.B. and Creel, M. 1991. Confidence Intervals for Evaluating Benefit Estimates from Dichotomous Choice Contingent Valuation Studies. Land Economics 67(1): 64-73.

Qin, L. and Zhai, L. (秦鲁, 翟留栓). 2015. On the Current Status and Development of Aquaculture insurance (中国水产养殖保险现状及发展特点分析). Fishery Information \& Strategy (渔业信息与 战略) 30 (1): 10-16.

Qin, T., Gu, X., Tian, Z., Huan, X.P., Jing, D. and Li, W. 2016. An Empirical Analysis of the Factors Influencing Farmer Demand for Forest Insurance: Based on Surveys from Lin'an County in Zhejiang Province of China. Journal of Forest Economics 24: 37-51.

Seifert, I., Botzen, W.J.W., Kreibich, H. and Aerts, J.C.J.H. 2013. Influence of Flood Risk Characteristics on Flood Insurance Demand: a Comparison between Germany and the Netherlands. Natural Hazards and Earth System Science 13: 1691-1705.

Shields, D.A. 2015. Federal Crop Insurance: Background, Congressional Research Service (CRS) Report. [Online]. Available from: https://fas.org/sgp/crs/misc/R40532.pdf [Accessed 9 August 2018].

Sigma. 2017. Natural Catastrophes and Man-made Disasters in 2016: A Year of Widespread Damages. [Online]. Available from: http://institute.swissre.com/research/library/sigma_2_2017_en.html [Accessed 9 August 2018].

Spence, A., Poortinga, W., Butler, C. and Pidgeon, N.F. 2011. Perceptions of Climate Change and Willingness to Save Energy Related to Flood Experience. Natural Climate Change 1: 46-49.

Sun, Y. (孙颢士). 2008. Several Models in the Practice of Policy Fishery Insurance in China (中国政策性 渔业保险实践中的几种模式). Proceedings of China Fishery Economic Expert Forum 2008 (2008 中 
国渔业经济专家论坛论文集): 31-37.

Sun, Y. (孙渘士). 2009. Discussion of Fishery Insurance System in Modern Fishery Construction (论现代 渔业建设中的渔业保险制度). Chinese Fisheries Economics (中国渔业经济) 6: 5-11.

Sun, F., Hong, D., Yang, J., Sun, Y. and Chen, J. (孙芙蓉, 洪东转, 杨婧, 孙圆圆, 陈景钻). 2010. Compulsory Education Situation of Fishing Villages in Cangnan Country from Fishermen's Perspective (基于渔民视角的苍南县渔村义务教育现状研究). Chinese Fisheries Economics (中国渔 业经济) 5: 148-152.

Teshome, H. and Bogale, A. 2015. Willingness to Pay for Rainfall Risk Insurance by Smallholder Farmers in Central Rift Valley of Ethiopia: the Case of Dugda and Mieso Districts. African Journal of Agricultural Research 10(28): 2738-2747.

Teweldemedhin, M.Y. and Kafidii, L. 2009. Risk Management Strategies of Cattle Farmers in Namibia: Case Study from Omaheke and Otjozondjupa Regions. Journal of Agricultural Extension and Rural Development 1(2): 63-70.

Tian, L. and Yao, P. 2015. Preferences for Earthquake Insurance in Rural China: Factors Influencing Individuals' Willingness to Pay. Natural Hazards 79: 93-110.

TJCS (Tianjin Finance Bureau, 天津市财政局). 2015. The Circular on the Financial Subsidy Policy of Fishery Mutual Insurance in Tianjin (天津市海洋渔业互助保险财政补贴政策通知). [Online]. Available from: http://www.tjcs.gov.cn/art/2015/11/12/art_1361_1265.html [Accessed 9 August 2018]. Wang, N. (王宁). 2011. Fishermen Become Trapped When Changing Their Jobs (渔民转业惑与困). [Online]. Nanfang Daily (南方日报) 6(1). Available: http://www.china-cfa.org/hotnew_9.asp. [Accessed 9 August 2018].

Wang, J. and Li, H. (王建国, 李华). 2013. The Status, Problems and Countermeasures of the Development of Aquaculture Insurance in China (我国水产养殖保险发展的现状、问题与对策). Insurance Studies (保险研究) 8: 79-83.

Wu, J. (吴江). 2010. Factors Influencing Fishermen's Decisions to Buy Fishing Insurance: A Case Study of Shayang Country in Hubei Province (渔民对渔业保险需求影响因素研究一一湖北省沙洋县为例). Journal of Huazhong Agricultural University (Social Sciences Edition) (华中农业大学学报（社会科 学版) 5: 54-58.

Ye, X. (叶晓凌). 2010. Factors Affecting the Demand and Supply of Marine Fishery Insurance (海洋渔业 保险需求与供给因素分析). Research on Development (开发研究) 6: 70-76.

Ye, X. and Luo, J. (叶晓凌, 罗剑朝). 2011. Analysis of the Impact of Subsidy Policy on Fishermen Participating in Mutual Insurance (补贴政策对渔民参与互助保险的影响分析). Fiscal Research (财 政研究) 12: 23-27.

Yuan, X., Tipparat, P., Zhang, Z. and Jing, X. 2017. Fishery and Aquaculture Insurance in China. FAO Fisheries and Aquaculture Circular: 1139.

Zekri S., Mbaga M.D. and Boughanmi, H. 2008. Fishermen Willingness to Participate in an Insurance 
Program in Oman. Marine Resource Economics 23: 379-391.

Zhang, D. and Stenger, A. 2014. Timber Insurance: Perspectives from a Legal Case and a Preliminary Review of Practices throughout the World. New Zealand Journal of Forestry Science 44(1): 1-7.

Zheng, H. and Wang, C. (郑慧, 王春阳). 2015. Strategy of Moral Hazard Controlling in Marine Disaster Insurance Market (海洋灾害保险市场道德风险防范策略研究). Marine Environmental Science (海洋 环境科学) 4: 536-539.

ZJCZT (Zhejiang Provincial Department of Finance, 浙江省财政厅). 2012. Interim Measures for the Management of Special Funds for Subsidies for Fishery Mutual Insurance (浙江省政策性渔业互助保 险 补 贴专项资 金管 理 暂 行 办法 ). [Online]. Available from: http://www.zjczt.gov.cn/art/2012/3/28/art_1190848_1614078.html [Accessed 9 August 2018].

ZJOAF (Oceanic and Fisheries Administrator of Zhejiang Province, 浙江省海洋与渔业局). 2017.

Aquaculture Mutual Insurance (政策性水产养殖互助保险). [Online]. Available from: http://www.zjoaf.gov.cn/zfxxgk/gkml/zcfg/jfwj/2017/04/06/2017040600003.shtml [Accessed 9 August 2018].

ZJOAF (Oceanic and Fisheries Administrator of Zhejiang Province, 浙江省海洋与渔业局). 2017. The Notice of Strengthening Aquaculture Mutual Insurance Pilot in Zhejiang (浙江省关于加强政策性水 产养殖互助保险试点工作的通知 ). [Online]. Available from: http://www.zjoaf.gov.cn/zfxxgk/gkml/zcfg/jfwj/2017/04/06/2017040600003.shtml [Accessed 9 August 2018].

\section{Appendix}

Insert Appendix here (containing Table 4 and Table 5) 
$\mathrm{Y}_{\mathrm{i}}$ $=\alpha_{0}+\alpha_{1}$ Age $_{i}+\alpha_{2}$ Exp $_{i}+\alpha_{3}$ Size $_{i}+\alpha_{4}$ Pro $_{i}+\alpha_{5}$ Inc $_{i}+\alpha_{6}$ Land $_{i}+\alpha_{7}$ Loss $_{i}+\alpha_{8}$ Edu $_{i}+\alpha_{9}$ AIn $_{i}$ $+\alpha_{10} \operatorname{CIn}_{\mathrm{i}}+\beta \operatorname{Bid}_{\mathrm{i}} \mathrm{i}=1, \cdots, 1,271$ 


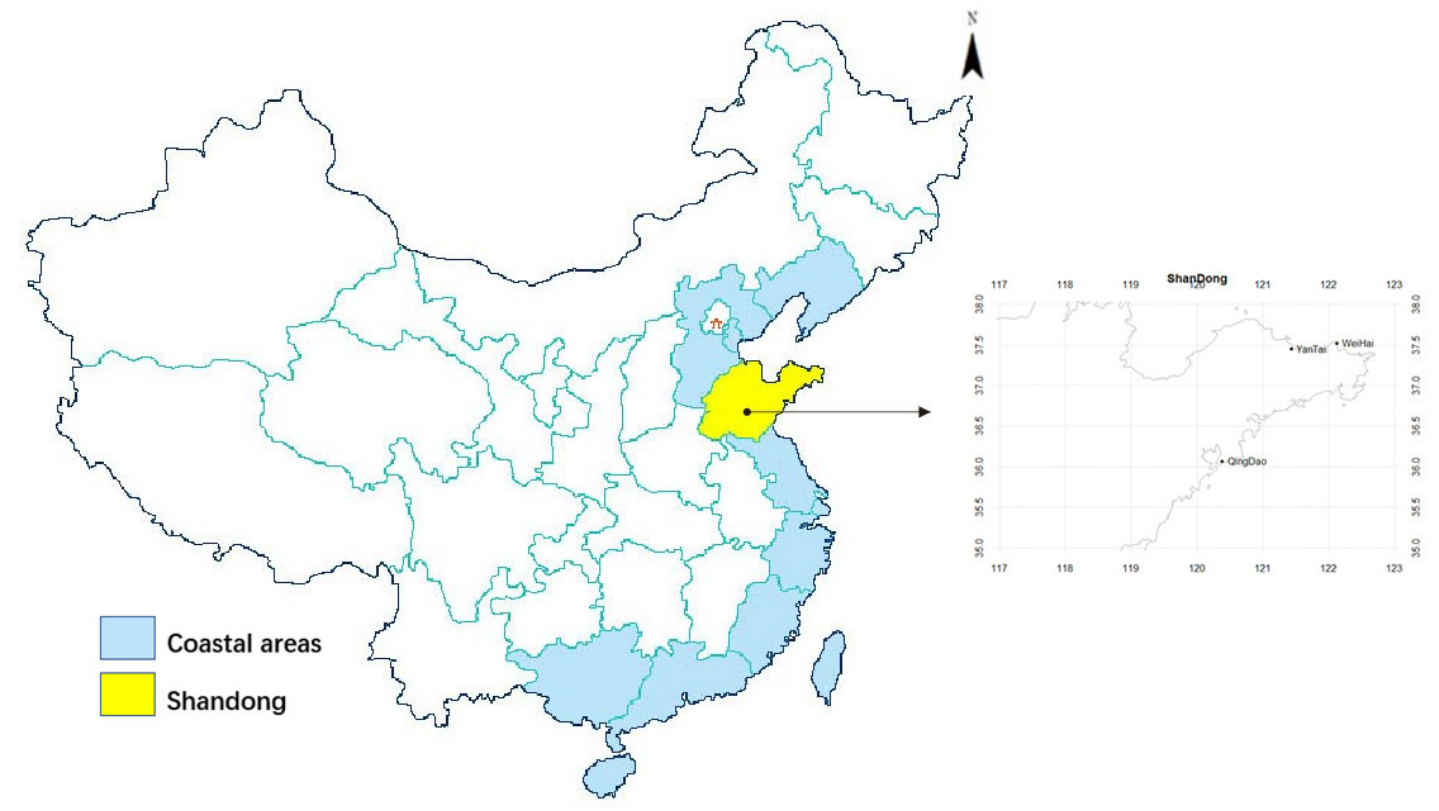


Figure 1 Map of China and the study area 
Table 2

Bid amount

\begin{tabular}{cccc}
\hline No. & Initial bid & Following higher bid & Following lower bid \\
\hline 1 & 50 & 100 & 25 \\
2 & 150 & 300 & 125 \\
3 & 250 & 500 & 225 \\
4 & 350 & 700 & 325 \\
5 & 450 & 900 & 425 \\
\hline
\end{tabular}


Table 3

The regression results

\begin{tabular}{|c|c|c|c|}
\hline Independent variables & Coefficient & S.E. & Sig. \\
\hline Age & -0.271 & 0.027 & $0.018^{*}$ \\
\hline Exp & -0.135 & 0.082 & $0.099 * *$ \\
\hline Size & 0.128 & 0.077 & $0.098 * *$ \\
\hline Pro & -0.820 & 0.402 & $0.041^{*}$ \\
\hline Inc & -0.054 & 0.027 & $0.044 *$ \\
\hline Land & 0.047 & 0.313 & $0.076 * *$ \\
\hline Loss & 0.497 & 0.118 & $0.000 *$ \\
\hline Edu & 0.750 & 0.173 & $0.000^{*}$ \\
\hline AIn & 0.788 & 0.174 & $0.000^{*}$ \\
\hline CIn & 0.302 & 0.164 & $0.065 * *$ \\
\hline $\mathrm{C}$ & 0.536 & 0.538 & 0.319 \\
\hline Bid & -0.041 & 0.213 & $0.027 *$ \\
\hline Willingness to pay & 579 & Confidence interval 95\% & $559.25-604.08$ \\
\hline
\end{tabular}

*Significant at 5\%;**Significant at 10\% . 
Table 4

Statistics of the variables

\begin{tabular}{|c|c|c|c|c|c|}
\hline & Variables & Categories & Respondents & $\begin{array}{l}\text { Pro. showing } \\
\text { WTP for } \\
\text { aquaculture } \\
\text { insurance }\end{array}$ & $\begin{array}{c}\text { Expected sign } \\
\text { of the } \\
\text { coefficient }\end{array}$ \\
\hline \multirow{10}{*}{$\begin{array}{l}\text { Personal } \\
\text { variables }\end{array}$} & \multirow{6}{*}{ Age (year) } & $<20$ & 6 & 0.833 & \multirow{6}{*}{-} \\
\hline & & $21-30$ & 175 & 0.783 & \\
\hline & & $31-40$ & 353 & 0.79 & \\
\hline & & $41-50$ & 431 & 0.777 & \\
\hline & & $51-60$ & 237 & 0.781 & \\
\hline & & $>60$ & 71 & 0.69 & \\
\hline & \multirow{4}{*}{$\begin{array}{c}\text { Farming } \\
\text { experience (year) }\end{array}$} & $0-5$ & 198 & 0.768 & \multirow{4}{*}{-} \\
\hline & & $6-15$ & 435 & 0.791 & \\
\hline & & $16-25$ & 330 & 0.812 & \\
\hline & & $\geq 25$ & 294 & 0.721 & \\
\hline \multirow{15}{*}{$\begin{array}{c}\text { Social } \\
\text { variables }\end{array}$} & \multirow{6}{*}{ Household size } & 1 & 27 & 0.852 & \multirow{6}{*}{-} \\
\hline & & 2 & 127 & 0.724 & \\
\hline & & 3 & 401 & 0.746 & \\
\hline & & 4 & 400 & 0.793 & \\
\hline & & 5 & 204 & 0.794 & \\
\hline & & $\geq 6$ & 117 & 0.855 & \\
\hline & \multirow{4}{*}{$\begin{array}{l}\text { Proportion of } \\
\text { household } \\
\text { members } \\
\text { in labour force }\end{array}$} & $0-1 / 4$ & 19 & 0.947 & \multirow{4}{*}{+} \\
\hline & & $1 / 4-1 / 2$ & 352 & 0.827 & \\
\hline & & $1 / 2-3 / 4$ & 469 & 0.783 & \\
\hline & & 3/4-1 & 387 & 0.705 & \\
\hline & \multirow{5}{*}{$\begin{array}{c}\text { Average annual } \\
\text { household income } \\
\text { (CNY) }\end{array}$} & $<10000$ & 111 & 0.766 & \multirow{5}{*}{+} \\
\hline & & $10000-40000$ & 720 & 0.792 & \\
\hline & & $40000-70000$ & 350 & 0.771 & \\
\hline & & $70000-100000$ & 75 & 0.733 & \\
\hline & & $>100000$ & 15 & 0.8 & \\
\hline \multirow{9}{*}{$\begin{array}{c}\text { Risk } \\
\text { variables }\end{array}$} & \multirow{5}{*}{$\begin{array}{l}\text { Landholding per } \\
\text { member of } \\
\text { household (Acres) }\end{array}$} & $0-0.5$ & 165 & 0.63 & \multirow{5}{*}{+} \\
\hline & & $0.5-1$ & 323 & 0.793 & \\
\hline & & $1-3$ & 607 & 0.817 & \\
\hline & & $3-10$ & 142 & 0.775 & \\
\hline & & $>10$ & 39 & 0.718 & \\
\hline & \multirow{4}{*}{$\begin{array}{l}\text { Average annual } \\
\text { loss of household } \\
(\mathrm{CNY})\end{array}$} & $0-2000$ & 546 & 0.72 & \multirow{4}{*}{+} \\
\hline & & $2000-4000$ & 536 & 0.826 & \\
\hline & & $4000-6000$ & 153 & 0.83 & \\
\hline & & $>6000$ & 14 & 0.929 & \\
\hline \multirow{8}{*}{$\begin{array}{l}\text { Attitude } \\
\text { variables }\end{array}$} & \multirow{6}{*}{$\begin{array}{c}\text { Discrete } \\
\text { education level of } \\
\text { the household } \\
\text { held (year) }\end{array}$} & Below primary $(<3)$ & 69 & 0.725 & \multirow{6}{*}{+} \\
\hline & & Primary(3-6) & 149 & 0.745 & \\
\hline & & Junior(6-9) & 579 & 0.765 & \\
\hline & & Senior(9-12) & 421 & 0.847 & \\
\hline & & Undergraduate(12-16) & 45 & 0.943 & \\
\hline & & $\begin{array}{l}\text { Postgraduates and } \\
\text { above }(>16)\end{array}$ & 2 & 1 & \\
\hline & \multirow{2}{*}{$\begin{array}{c}\text { Awareness } \\
\text { towards } \\
\text { aquaculture }\end{array}$} & Yes & 935 & 0.83 & \multirow[b]{2}{*}{+} \\
\hline & & No & 339 & 0.634 & \\
\hline
\end{tabular}




\begin{tabular}{|c|c|c|c|c|}
\hline insurance $(\%)$ & & & & \\
\hline $\begin{array}{l}\text { Awareness } \\
\text { towards other }\end{array}$ & Yes & 805 & 0.825 & \multirow{2}{*}{+} \\
\hline $\begin{array}{c}\text { commercial } \\
\text { insurance }(\%)\end{array}$ & No & 458 & 0.694 & \\
\hline
\end{tabular}

Table 5

Breakup of variables according to WTP responses

\begin{tabular}{cccccc}
\hline Variables & YY & YN & NY & NN & Overall sample \\
\hline Age & 17.3 & 46.7 & 62.9 & 68.1 & 42.3 \\
Farming experience (Exp) & 2.32 & 11.4 & 17.02 & 27.02 & 17.07 \\
Household size (Size) & 5.82 & 3.56 & 2.4 & 1.6 & 3.8 \\
Proportion of household members & 0.11 & 0.5 & 0.74 & 0.82 & 0.60 \\
in labour force (Pro) & & & & & \\
Average annual household income (Inc) & 8325.11 & 23419.33 & 87633.41 & 112400.9 & 36472.90 \\
Landholding per member of household (Land) & 6.81 & 1.34 & 1.1 & 0.31 & 2.27 \\
Average annual loss of household (Loss) & 8214.15 & 6099.08 & 3134.56 & 1321.4 & 2402.99 \\
Discrete education level of the household held (Edu) & 9.2 & 6.72 & 5.8 & 3.25 & 9.04 \\
Awareness towards aquaculture insurance (AIn) & 77.78 & 51.04 & 41.13 & 32 & 73.45 \\
Awareness towards other commercial insurance (CIn) & 77.08 & 47.32 & 35.49 & 29.50 & 63.23 \\
Response rate to WTP (\%) & 36.6 & 22.9 & 19.32 & 21.18 & 100 \\
\hline
\end{tabular}


Table 1

Main products of fishery insurance in China

\begin{tabular}{|c|c|c|}
\hline $\begin{array}{l}\text { Insurance } \\
\text { types }\end{array}$ & Name of products & Insurer and coverage \\
\hline \multirow{5}{*}{$\begin{array}{l}\text { Fishing vessel } \\
\text { insurance }\end{array}$} & $\begin{array}{l}\text { "Anxin Escort Shield" } \\
\text { fishing boat } \\
\text { comprehensive insurance } \\
\text { (AAIC, not dated) }\end{array}$ & $\begin{array}{l}\text { Provided by Shanghai Anxin Agricultural Insurance Co. Ltd. } \\
\text { Covers damage to the hull and crew caused by natural disasters and accidents on fishing } \\
\text { boats. }\end{array}$ \\
\hline & $\begin{array}{l}\text { Nansha fishing boat } \\
\text { foreign mutual insurance } \\
\text { (CFMI, 2016) }\end{array}$ & $\begin{array}{l}\text { Provided by China Fisheries Mutual Insurance Association. } \\
\text { Covers full and partial loss of fishing vessels; loss of abandoned fishing gear so as to } \\
\text { avoid being arrested by foreign military police; loss of machinery, equipment and } \\
\text { others certificated on the hull to avoid clashes with foreign military police and } \\
\text { collisions with other ships; salvage or salvage fees that are deemed necessary and } \\
\text { reasonable for rescue or relief measures to prevent or reduce damage. } \\
\text { The premium rate is determined by the insurer based on the quality and age of the } \\
\text { vessels etc. }\end{array}$ \\
\hline & $\begin{array}{l}\text { Fishing boat mutual } \\
\text { insurance (CFMI, 2016) }\end{array}$ & $\begin{array}{l}\text { Provided by China Fisheries Mutual Insurance Association. } \\
\text { Covers loss of the hull and the equipment on board caused by wind, natural disasters, } \\
\text { floods, earthquake, tsunamis, lightning strikes, landslides, debris flows, ice disasters, } \\
\text { fires, explosions, collisions, or missing in the sea for more than two months. } \\
\text { The premium rate is determined by the insurer based on the quality and age of the } \\
\text { vessels and etc. }\end{array}$ \\
\hline & $\begin{array}{l}\text { Fishing boat mutual } \\
\text { insurance of Hainan } \\
\text { (CFMI, 2016) }\end{array}$ & $\begin{array}{l}\text { Same as the above but only provided in Hainan province. } \\
\text { The premium rate ranges from } 0.7 \text { to } 3.05 \text { according to the material, age, power of the } \\
\text { hull. }\end{array}$ \\
\hline & $\begin{array}{l}\text { Fishing boat commercial } \\
\text { insurance (CNTAIPING, } \\
\text { not dated) }\end{array}$ & $\begin{array}{l}\text { Provided by the China Ping An Insurance (Group) Company Ltd., China Pacific } \\
\text { Insurance (Group) Co. Ltd., China Continent Insurance and other state-owned property } \\
\text { insurance companies. } \\
\text { Covers the total or partial loss of fishing vessels caused by natural disasters or accidents } \\
\text { as well as general salvage, and the navigation area is limited to that specified in the } \\
\text { insurance policy. } \\
\text { The premium rate is determined by the insurer according to the quality and age of the } \\
\text { vessels and etc. }\end{array}$ \\
\hline \multirow{4}{*}{ Life insurance } & $\begin{array}{l}\text { Personal safety mutual } \\
\text { insurance (CFMI, 2016) }\end{array}$ & $\begin{array}{l}\text { Provided by China Fisheries Mutual Insurance Association. } \\
\text { Covers accidental death or accidental disability of policy-holders engaging in fishery } \\
\text { production or serving fishery production. } \\
\text { The actual premium varies as different provinces and cities have different premium } \\
\text { subsidies. }\end{array}$ \\
\hline & $\begin{array}{l}\text { Personal accident } \\
\text { insurance at sea (Hainan } \\
\text { Province) (CFMI, 2016) }\end{array}$ & Almost the same as the above, but only provided in Hainan Province. \\
\hline & $\begin{array}{l}\text { Employers' liability } \\
\text { mutual insurance (CFMI, } \\
\text { 2016) }\end{array}$ & $\begin{array}{l}\text { Provided by China Fisheries Mutual Insurance Association. } \\
\text { Covers general employer's liability insurance and compensates for accidental death or } \\
\text { disability of employees engaging in fishery production or serving fishery production. } \\
\text { The premium rate ranges from } 10 \% \text { to } 100 \% \text { according to the damage and is negotiated } \\
\text { between the insured and the CFMI. }\end{array}$ \\
\hline & $\begin{array}{l}\text { Employers' foreign } \\
\text { mutual liability insurance } \\
\text { (Nansha) (CFMI, 2016) }\end{array}$ & $\begin{array}{l}\text { Provided by China Fisheries Mutual Insurance Association. } \\
\text { Covers financial loss as well as death or disability of employees working on fishing } \\
\text { vessels in the traditional waters of the Nansha Islands in acts of violence by foreign } \\
\text { military police (gun) strikes, arrests, and etc. } \\
\text { The indemnity is determined by the insured and the association, and the premium is } \\
\text { equal to the indemnity multiplied by the premium rate, which varies from 5\% to } 100 \% \\
\text { according to the disability level. }\end{array}$ \\
\hline \multirow{2}{*}{$\begin{array}{l}\text { Aquaculture } \\
\text { insurance }\end{array}$} & $\begin{array}{l}\text { "Safe to Fortis" } \\
\text { aquaculture insurance } \\
\text { (AAIC, not dated) }\end{array}$ & $\begin{array}{l}\text { Provided by Shanghai Anxin Agricultural Insurance Co., Ltd. for fish farmers or } \\
\text { agricultural entities engaging in river crab aquaculture in Shanghai, Zhejiang and } \\
\text { Jiangsu only. } \\
\text { Covers loss of crabs and the gear destroyed or inundated by flood during the coverage } \\
\text { period. }\end{array}$ \\
\hline & $\begin{array}{l}\text { Aquaculture insurance } \\
\text { (GAPI, not dated) }\end{array}$ & $\begin{array}{l}\text { Provided by the Groupama-AVIC Property Insurance Co., Ltd. } \\
\text { Covers fish loss caused by infection, major diseases, natural disasters, accidents, water } \\
\text { pollution and floating heads to fish farmers and aquaculture companies. The insurance } \\
\text { premium is negotiated between the applicant and the insurer with reference to the }\end{array}$ \\
\hline
\end{tabular}


species and age of the fish.

The subsidy takes up to $50 \%$ to $60 \%$ of the premium, provided by the municipal and county government in Jilin, Sichuan, Shanxi (山西) and Shanxi (陕西).

Aquaculture mutual insurance (ZJOAF, 2017)

Provided by Zhejiang Fisheries Mutual Insurance Association.

Covers loss of designated crabs, shellfish, algae, etc. caused by natural disasters, sudden diseases, and so on.

The premium ranges from CNY32 to 100 per CNY1,000 insured value.

Provided by Guo Yuan Agriculture Insurance Co., Ltd.

Aquaculture insurance

Covers loss caused by natural disasters, aquatic hypoxia for designated fresh water fish

(GYNYBX, not dated)

in Anhui province.

The premium ranges from CNY600 to 4,000 per 750-kilogram aquaculture production.

Typhoon index

Provided by Fujian Fisheries Mutual Insurance Association.

aquaculture insurance

Covers loss caused by typhoon between 1st June and 31st October every year in Fujian province.

(FFMI, 2018)

The premium rate ranges from $5.5 \%$ to $7 \%$.

Source: compiled by authors. 